Sarah H. Northam

\title{
Cruising through the '50s A decade in ACRL history
}

W

hen looking at the decade of the 1950s through the lens of ACRL, it is easy to see the zeitgeist of the time. The Cold War was in full swing, and there was much discussion of how to handle the impending crisis. For example, the American Association of Museums asked Milton Lord, past president of ALA, to use his connection to both ALA and ACRL to determine if "national library organizations would be interested in making an appeal to the federal government" to establish regional shelters around the United States. ${ }^{1}$

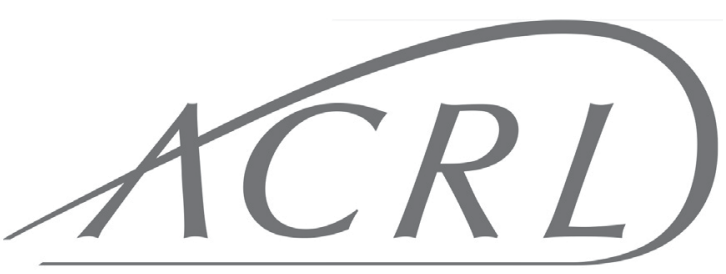

75 TH ANNIVERSARY

\section{Association of College \& Research Libraries A DIVISION OF THE AMERICAN LIBRARY ASSOCIATION \\ 1940-2015 75 Years of Advancing Learning \& Transforming Scholarship}

boom in undergraduate libraries. Harvard University added a library in the late 1940s, specifically for their undergraduate students. The University of Michigan followed, adding an undergraduate library in $1958 .{ }^{4}$ In 1949 , ACRL surveyed library construction projects and 24 libraries across the United States responded. 5

A 1952 survey by the ACRL Building Committee found that new 100 libraries would be built before $1960 .{ }^{6} \mathrm{Ar}-$ ticles in College and Research Libraries highlighted many new libraries throughout the decade, including the Linda Hall Library at the University of Kansas in 1955, and the University Library at the University of New Hampshire in $1959,7,8$

The boom in academic libraries benefited ACRL: membership rose from 4,623 in 1950 to 7,084 in 1959 , an increase of more than $53 \%{ }^{9}$ At the same time there was interest in increasing ACRL institutional member-

Sarah $\mathrm{H}$. Northam is head of research and instruction services at Texas A\&M University-Commerce's James G. Gee Library, email: sarah.northam@tamuc.edu (c) 2014 Sarah H. Northam 
ship. Beginning in 1953, ACRL appointed State Representatives who were tasked to "act as spokesmen for ACRL in their area: [to] be kept informed . . . of ACRL contacts with libraries in their areas. It is hoped they will be active in reporting state needs, state attitudes, and personnel recommended for committee assignments." ${ }^{10}$ ACRL members advocated for improved education of librarians as seen in CERL articles like "The Education of the Librarian," as well as for academic recognition and faculty status. ${ }^{11}$

In 1955, the impending reorganization of ALA and its possible impact on ACRL began to appear in the ACRL Board of Directors minutes. By 1956 it was determined that the divisions would be the representative of ALA for their "special areas" and "respective fields." In addition, the ALA executive secretary would act as liaison between the divisions, with the divisional secretaries reporting to the executive secretary. The reorganization would provide an "effective and economical integration of the whole of ALA headquarters." ACRL President Robert W. Orr (1956-57) approved the plan, stating:

In my opinion ACRL is potentially in a better position now to grow and develop to heights not hitherto possible because the reorganization is bringing about an integration of the divisions which permits maximum flexibility and force of emphasis. If ACRL's membership continues to grow . . . and if the association's program activities develop to the new stature anticipated for them, then the reorganization will indeed be a success. ${ }^{12}$

The reorganization would revise the dues structure to allow for better financial support to the various divisions, and ALA Headquarters would take on the responsibility of providing for the financial needs of the executive secretaries. ${ }^{13}$

ACRL adopted a new constitution at Midwinter in 1957 which defined the scope of the division ("those libraries which support formal education above the secondary level or which maintain research collections") and changed the name from the Association of College and Reference Libraries to the Association of College and Research Libraries. ${ }^{14}$ "Reference Libraries" was removed since it did not accurately reflect the purpose or direction of the division.

During the 1950s, accreditation standards for postsecondary institutions were strengthened and ACRL followed by developing standards for college libraries. In October of 1951, L. H. Kirkpatrick, a librarian at the University of Utah, felt that the creation of the National Commission on Accrediting gave "library leaders a chance to express themselves with regard to the [regional] accrediting process." He went on to write that "since accrediting is peculiarly tied in with educational agencies, and since libraries are vital to all training programs, it is my hope that the American Library Association will offer to rate libraries and library positions for all accrediting agencies and to criticize for this new commission past practices in the rating of libraries." 15

The ACRL Committee on Standards was authorized in 1957 to create standards for college libraries. Over the next two years, the committee met with regional accrediting agencies, library leaders, and ACRL membership as they developed the framework for the standards. "The Preparation of the Standards for College Libraries," from July 1959, explains that the "committee's main aim was to provide flexible standards, based on firm principles. It was felt that only an instrument that met both requirements would serve American higher education effectively in a period of tremendous expansion and fundamental change." ${ }^{16}$ According to David Kaser this was the "first real set of 'Standards for College Libraries' to enjoy consensual support of the profession.

This highly influential document was instrumental for some 15 years in gaining improvement in college library resources. ${ }^{17}$ The standards included guidelines on the function of the college library, structure 
and government, budget, staff, and the library collection. Specific quotas included a minimum of " 50,000 carefully chosen volumes" that should be increased by 50,000 volumes for 600 students, then 10,000 volumes for each "additional 200 students." 18 ACRL would go on to develop individual standards for two-year institutions and university libraries.

\section{Notes}

1. C. W. David, "Brief of Minutes, Association of Research Libraries, Feb. 1, 1951, Chicago," College and Research Libraries, 12, no. 3 (July 1951): 279, retrieved August 30, 2014, from http://crl.acrl.org/content/12/3/276.full. pdf + html.

2. J. Forest and K. Kinser, Higher education in the United States: An encyclopedia (Santa Barbara, CA: ABC-CLIO, 2002).

3. National Center for Education Statistics, 120 Years of American Education: A Statistical Portrait (Washington, D.C. : U.S. Department of Education, 1993), 75.

4. E. G. Holley, "Building a Firm Foundation: ACRL Leadership, 1939-1989," College and Research Libraries News 6 (June 1989): 464.

5. R. H. Muller, "Library Building Construction Among College and Universities, 1950," College and Research Libraries, 11, no. 3 (July 1950): 260, retrieved August 30, 2014, from http://crl.acrl.org/content/11/3/259.full. pdf + html.

6. H. D. Stallings, "College and university library buildings: A ten-year forecast, 19501960," College and Research Libraries, 13 no. 2 (April 1952): 136, retrieved August 30, 2014 , from http://crl.acrl.org/content/13/2/136. full.pdf + html?sid=f60144cf-71c3-47ef-84ef7392a39095c7.

7. J. C. Shipman, "Linda Hall Library," College \& Research Libraries, 16, no. 2, (April 1955): 138-14, retrieved August 30, 2014, from http://crl.acrl.org/content/16/2/138. full.pdf + html? sid $=500799$ cd-a 9 b0-4aad-8f $24-$ 3083 dc627603.

8. T. Brackett, "Under One Roof: the University of New Hampshire's new library,"
College and Research Libraries, 20, no. 3 (May 1959): 197-201, retrieved August 30, 2014, from http://crl.acrl.org/content/20/3/197. full.pdf + html? sid= 500799 cd-a9b0- 4 aad $-8 f 24-$ 3083 dc627603.

9. C. Hale, (1976). The Origin and Development of the Association of College and Research Libraries, 1889-1960 (Bloomington, Indiana: Indiana University, 1976): 294, retrieved August 30, 2014, from https://proxy. tamuc.edu $: 2048 /$ login?url=http:// proxy . tamuc.edu:10617/docview/302812230?acco untid $=7083$.

10. ACRL, "ACRL State Representatives," College \& Research Libraries, 14, no. 3 (July 1953): 328, retrieved August 30, 2014, from http://crl.acrl.org/content/14/3/320.full. pdf + html.

11. G. Leyh, "The Education of the Librarian," College \& Research Libraries, 15, no. 2 (April 1954): 140-147.

12. R. Orr, "ACRL and the reorganization," College and Research Libraries, 18, no 1, (January 1957):37, retrieved August 30, 2014, from http://crl.acrl.org /content/18/1/36.full.pdf+html.

13. Hale, Origin and Development of ACRL.

14. ACRL, "ACRL board of directors midwinter 1957 meetings," College \& Research Libraries, 18, no 3 (May 1957): 224, retrieved August 2014, from http://crl.acrl.org/content/18/3/222.full.pdf+html.

15. L. Kirkpatrick, "The accreditation of libraries and library schools," College \& Research Libraries, 12 no 4, (October 1951):346, retrieved August 30, 2014, from http://crl.acrl.org/content/12/4/346.full. pdf + html.

16. ACRL, "The preparation of the Standards for College Libraries," College $\&$ Research Libraries 20, no 4 (July 1959): 273, retrieved August 30, 2014, from http:// crl.acrl.org/content/20/4/273.full.pdf + html.

17. D. Kaiser, "A century of academic librarianship, as reflected in its literature," College E Research Libraries 37 no. 2 (March 1976): 116.

18. Ibid., 278. n 